\title{
Impact of Seed Priming on Proline Content and Antioxidant Enzymes to Mitigate Drought Stress in Rice Genotype
}

\author{
M.K. Samota*, M. Sasi and A. Singh \\ Division of Biochemistry, IARI, New Delhi-110012, India \\ *Corresponding author
}

\author{
A B S T R A C T
}

Keywords

Superoxide dismutase (SOD), Catalase (CAT), Peroxidase (POD), Nagina-22 (N-22), Pusa sugandh-5 (PS-5), Methyl-jasmonate (MJ), Paclobutrazol (PBZ)

Article Info

Accepted:

25 April 2017

Available Online:

10 May 2017
Drought is one of the major problems of crop production in most of the countries, particularly in rice growing areas. Rice (Oryza sativa L.), is one of the major food grain cereal crops of the Indian and the world subcontinent. It belongs to the family Graminae (Poaceae) and is a model system for cereal biology because of its smaller genome size of $430 \mathrm{Mb}$ that spans across 12 chromosomes. The rice varieties in this study showed differential responses for proline accumulation and enzymatic activities measured. The scavenging system in drought tolerant variety nagina-22 exhibited higher CAT, POD and SOD activities, than in the drought susceptible variety (pusa sugandh-5) drought-susceptible variety, PS-5 was markedly affected even at the lowest drought level used. The activity of antioxidant enzymes CAT, POD and SOD in the drought tolerant and drought susceptible varieties increased markedly during drought stress. Drought tolerance of the rice varieties associated with build up of antioxidant enzymes and proline. Among the biotic elicitors, MJ was found to be the most effective priming reagent, followed by PBZ. Present findings could be explored further to mitigate drought stress in order to improve rice yield in dry land areas.

\section{Introduction}

Drought is one of the major abiotic stresses that severely affect and reduce the yield and production of crops up to $65 \%$ (Thakur et al., 2010; Akram et al., 2013). Priming seeds with most favourable concentration of phytohormone have shown to be beneficial to growth and yield of some crops by increasing nutrient reserves through increased physiological activities and root proliferation (Singh and Dara, 1971). Diminish the harmful effects of stresses by the PGR (Datta et al., 1998). The generation of ROS is limited or scavenged by an antioxidant system including antioxidant compounds (ascorbate, SA, GSH, Vit-k) and antioxidant enzymes like SOD, APX and CAT (Foyer and Noctor, 2003). The retort of plants to drought stress is complex and involves changes in their morphology, physiology and metabolism. Decrease of plant growth is the most typical symptom of drought stress (Sairam and Srivastava, 2001). Drought stress leads to accumulation of ROS in chloroplast and mitochondria, causing oxidative burst. ROS molecules are singlet oxygen, superoxide anion radicals, hydroxyl radicals and hydrogen peroxide. Plants under 
drought stress display some defense mechanisms to protect themselves from the damaging effect of oxidative stress. Plants with high induced antioxidant levels have better tolerance and resistance to oxidative damage (Parida and Das, 2005). The ROS scavenging mechanism is among the common defence responses against abiotic stresses (Vranová et al., 2002). To detoxify ROS, plants can intrinsically develop different types of antioxidants reducing oxidative damage and conferring drought tolerance. The ROS scavengers are antioxidant enzymes containing SOD, APX and CAT (Demiral and Turkan, 2005; Khan and Panda, 2008).

The aim of this work was to study the comparative effects of different concentrations of elicitors on proline accumulation and antioxidant enzyme activities (e.g., CAT, POD and SOD) of two rice varieties.

\section{Materials and Methods}

\section{Seed material and priming}

Seed material of two contrasting rice genotypes- Nagina-22 (N-22) and PusaSugandh-5 (PS-5). Seeds of the contrasting rice genotypes were sterilized with $0.1 \%$ mercuric chloride $\left(\mathrm{HgCl}_{2}\right)$ solution for $4 \mathrm{~min}$ and thoroughly washed with distilled water. Three sets of seeds in triplicate were primed with concentration $(100 \mu \mathrm{M})$ of biotic elicitors /priming reagent according to the method given by Afzal et al., (2006) for methyl jasmonate (MJ), and Pill and Gunter (2001) for Paclobutrazol (PBZ). Primed and control seeds (three in each $4 / 4$ inches pot size) were grown in phytotron under controlled conditions. Irrigation of the seedlings with the half strength Hoagland solution was carried forwarded for 7 weeks. Drought stress was induced on 7 weeks-old seedlings by withholding water for 6 days. The shoot samples from the two biological and three technical replicates were harvested and stored for biochemical studies.

\section{Proline determination}

Proline was extracted from $100 \mathrm{mg}$ of leaf sample by using ninhydrin reagent in $3 \%$ (w/v) aqueous sulfosalicylic acid (Bates et al., 1973). The organic toluene phase was separated and absorbance of red colour developed was read at $520 \mathrm{~nm}$. Concentration of Proline (mg g-1 FW) was determined using calibration curve.

\section{Enzyme extraction}

Grinding Leaf sample (400 mg) in liquid nitrogen and finely ground by pestle and motor than the powder was added to $10 \mathrm{~mL}$ of phosphate buffer ( $\mathrm{pH} 7.0)$. Centrifugation of homogenate at $15000 \times \mathrm{g}$ for $10 \mathrm{~min}$ at $4 \mathrm{oC}$ and supernatant was used as enzyme source for CAT, SOD and POD assays. Assays of Antioxidant Enzyme Activities.

\section{Assay of CAT activity}

The assay mixture in total quantity of $3 \mathrm{ml}$ contained $0.5 \mathrm{~mL}$ of $0.2 \mathrm{M} \mathrm{H}_{2} \mathrm{PO}_{4}^{-} \mathrm{pH} 7.0$ ), $0.3 \mathrm{~mL}$ of $(\mathrm{v} / \mathrm{v}) \mathrm{H} 2 \mathrm{O} 2$ and $0.1 \mathrm{ml}$ of enzyme and made $3 \mathrm{ml}$ by adding DW. The reaction was started by adding enzyme and vary in optical compactness was measured at $240 \mathrm{~nm}$ at 0 min and $3 \mathrm{~min}$ on UV-Vis spectrophotometer. The molar extinction coefficient of $\mathrm{H}_{2} \mathrm{O}_{2}$ at $240 \mathrm{~nm}$ was taken as 36 $\mu$ mol- $1 \mathrm{~cm}-1$ and the results were expressed as $\mu$ mol H2O2 min-1 g -1 protein (Luck, 1974; Aebi and Bergmeyer, 1983).

\section{Assay of SOD activity}

$3 \mathrm{ml}$ of reaction mixture containing $0.1 \mathrm{ml}$ of $1.5 \mathrm{M}$ Na2CO3, $0.2 \mathrm{ml}$ of $200 \mathrm{mM}$ methionine, $0.1 \mathrm{ml}$ of $3 \mathrm{mM}$ EDTA, $0.1 \mathrm{ml}$ of $2.25 \mathrm{mM}$ NBT, $1.5 \mathrm{ml}$ of $100 \mathrm{mM}$ potassium phosphate buffer ( $\mathrm{pH} 7.5), 1 \mathrm{ml}$ of distilled 
water and $0.05 \mathrm{ml}$ of enzyme samples. One tube was taken as control. Reaction was started by adding $0.1 \mathrm{ml} 60 \mu \mathrm{M}$ riboflavin and placing the tubes below a light source of two $15 \mathrm{~W}$ fluorescent lamps for $15 \mathrm{~min}$ than reaction was stopped by switching off the light. Tubes are covered by black cloth. Absorbance was recorded at $560 \mathrm{~nm}$. An illuminated blank without protein gave the maximum reduction of NBT, and therefore, the maximum absorbance at $560 \mathrm{~nm}$. SOD activity is presented as absorbance of blank minus absorbance of sample, giving the total inhibition, calculated per $\mu \mathrm{g}$ protein. The activity of SOD was expressed as $\mathrm{U}$ mg -1 protein. One unit of activity is the amount of protein required to inhibit $50 \%$ initial reduction of NBT under light (Beauchamp and Fridovich, 1971; Dhindsa et al., 1981).

\section{Assay of POD activity}

The assay mixture of $3 \mathrm{ml}$ contained $1.5 \mathrm{ml}$ of $0.1 \mathrm{M}$ phosphate buffer (pH 7.0), $1 \mathrm{ml}$ freshly prepared $10 \mathrm{mM}$ guaiacol, $0.1 \mathrm{ml}$ enzyme extract and $0.1 \mathrm{ml}$ of $12.3 \mathrm{mM} \mathrm{H} 2 \mathrm{O} 2$. Initial absorbance was read at $436 \mathrm{~nm}$ and then increase in the absorbance was noted at the interval of $30 \mathrm{~s}$ on UV-Vis spectrophotometer. Activity was calculated using the $€ 26.6 \mathrm{mM}-1 \mathrm{~cm}-1$ for the oxidized tetraguaiacol polymer. Enzyme activity was $\mu$ mol guaiacol oxidized min-1 g -1 protein (Putter, 1974; Jebara et al., 2005).

\section{Results and Discussion}

\section{Proline content}

Proline content was found to increase $27 \%$ on drought stress imposition in the drought tolerant $(\mathrm{N}-22)$ genotype while it was found that no significant difference in susceptible genotype. It was found that the proline content increases after seed priming and a significant increase in both genotypes after drought imposition (Figure 1).

\section{SOD activity}

SOD activity does not show significant differences in control as well as treated sample. SOD activity higher in drought tolerant genotype than the susceptible ones after drought imposition (Figure 2).

\section{CAT activity}

Higher CAT activity observed in tolerant genotype than the susceptible ones, maximum activity observed in MJ treated tolerant genotypes after drought. Slightly increased activity found in susceptible ones in MJ and PBZ treated genotype (Figure 3).

\section{POD Activity}

Peroxidase activity not observed so much significant in both tolerant and susceptible genotypes after treatment. In both genotypes very low higher activity observed after treatments (Figure 4).

During vegetative growth stage the results obtained from the work confirmed that the rice varieties displayed diverse variation in drought tolerance. We identified the most drought tolerant variety shows higher activity of antioxidant enzymes and shows higher content of proline. The proline content of rice varieties increases in both drought susceptible and drought tolerant under drought condition (Figer 1). Osmotic potential of cell balanced by the proline accumulation in plants under water stress (Pireivatloum et al., 2010). Tolerance to drought-stress in higher plants correlates to the levels of antioxidant systems and substrates (Athar et al., 2008). To combat the effects of drought induced oxidative stress, plants develop a complex mechanism of antioxidant system. ROS scavenging enzymes have higher activity in tolerant genotypes when compared to susceptible ones. 


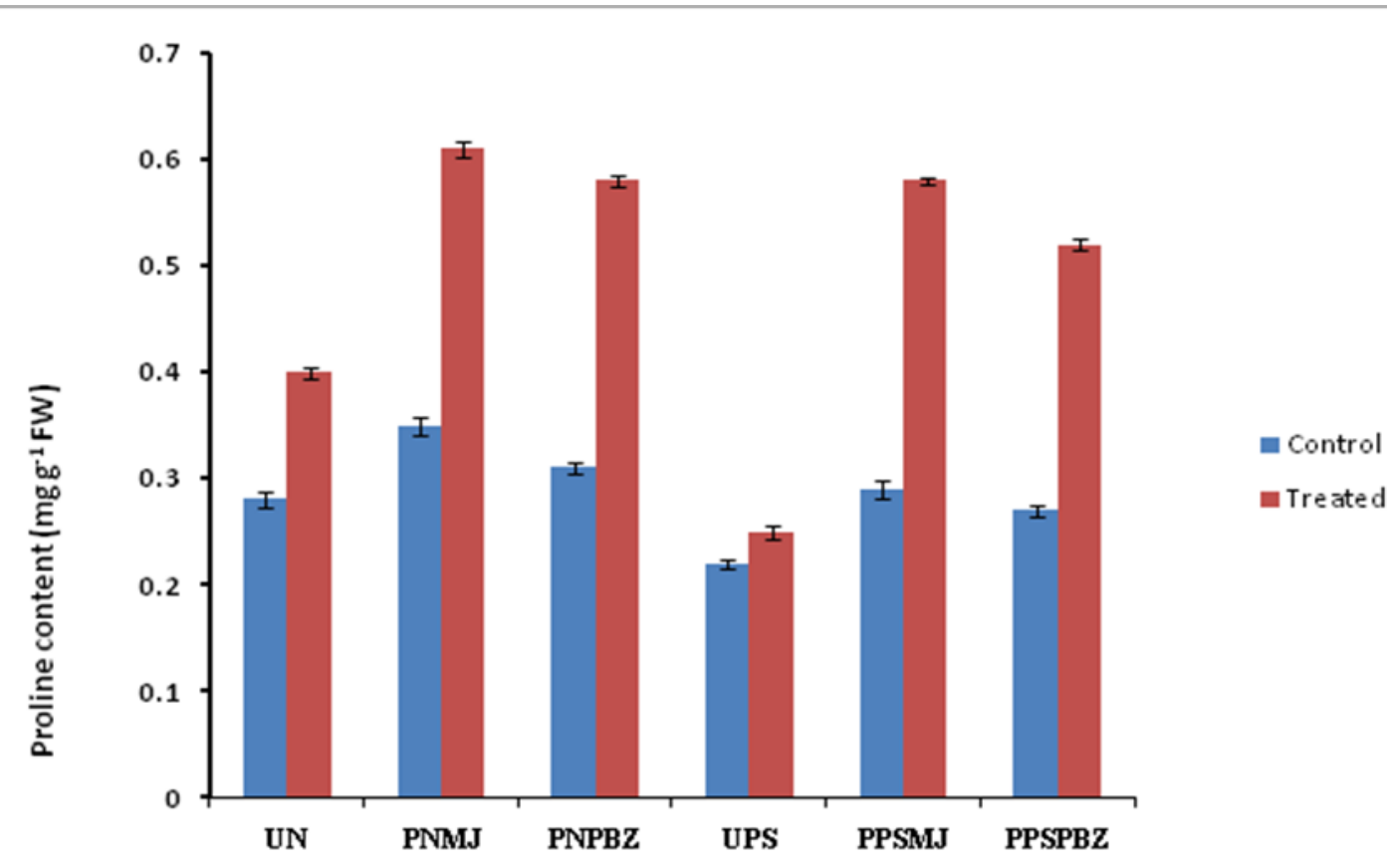

Figure:1Proline contentin shoot region of contrasting rice genotypes-Pusa sugandha- 5 (droughtsusceptible) and Nagina-22(drought-tolerant) under drought condition against priming with biotic elicitors- methyl jasmonate (MD) and paclobutrazol (PBZ). Bars represent standard deviations.

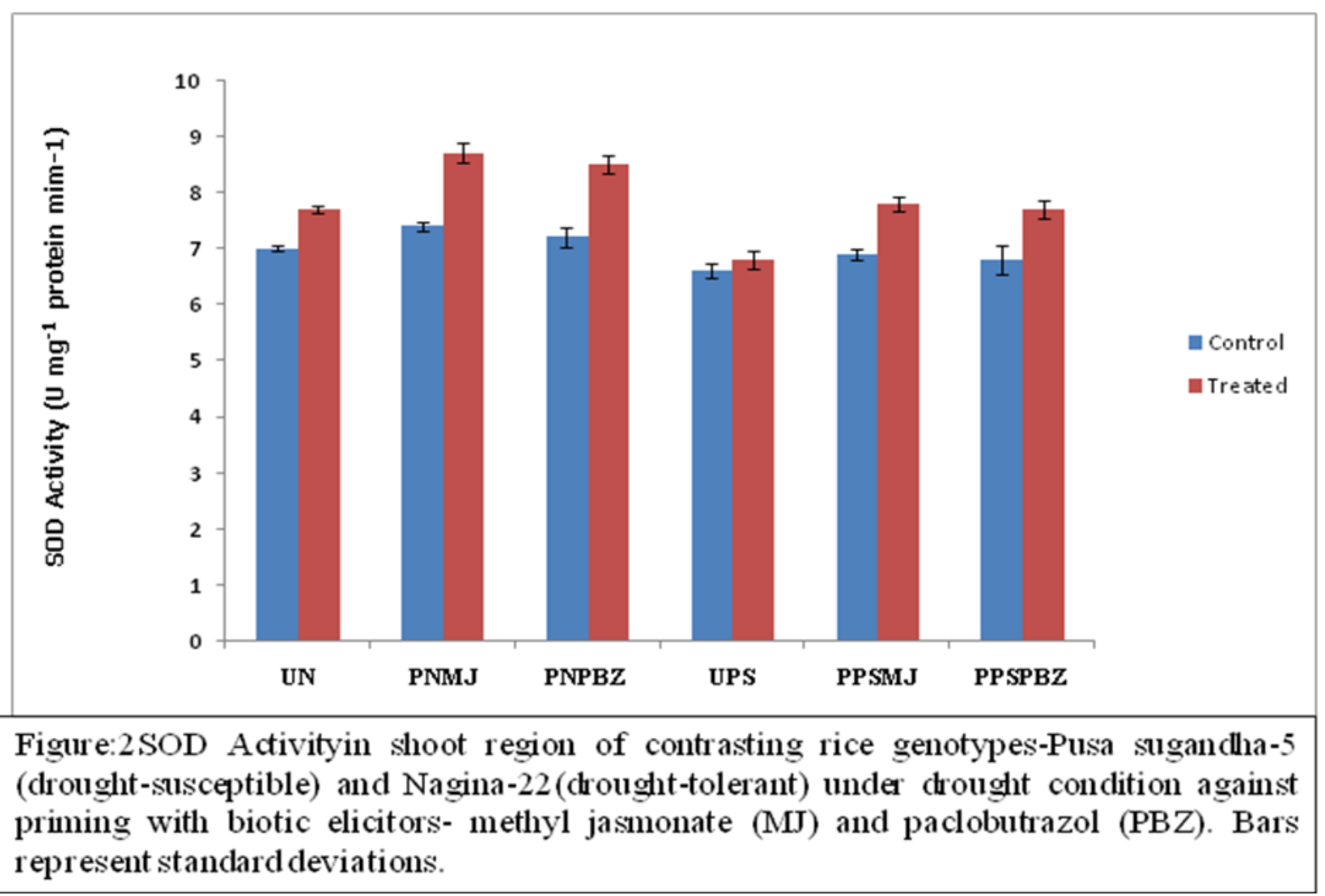




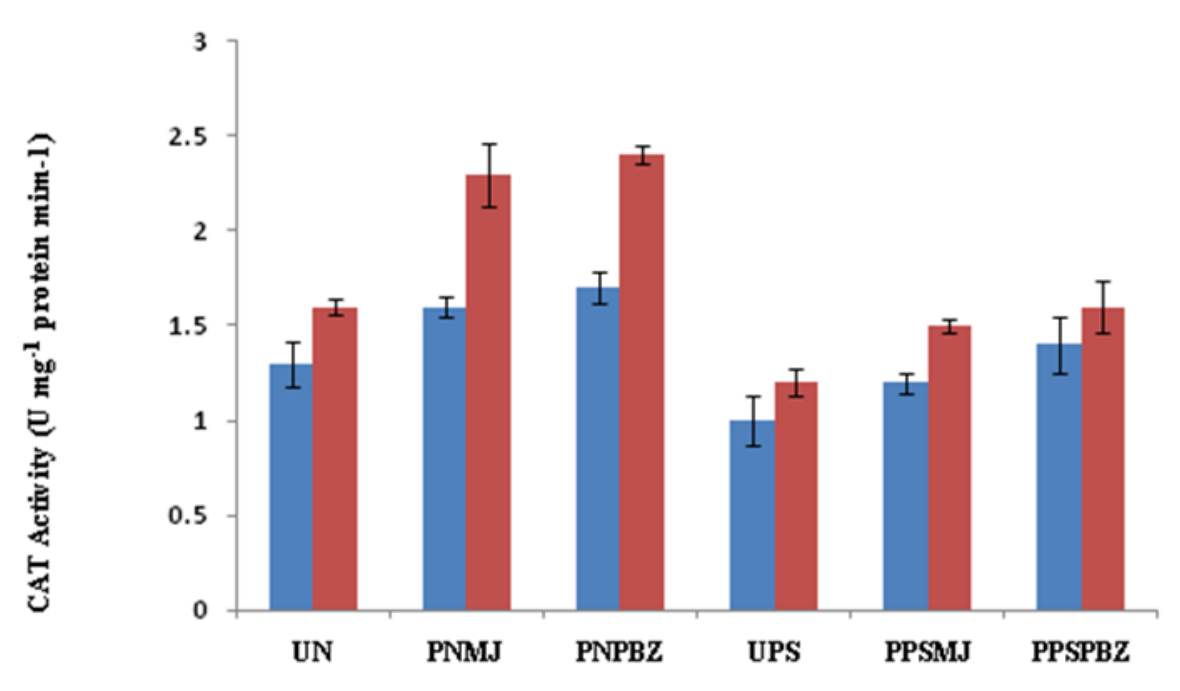

Control

- Treated

Figure:3 CAT Activity in shoot region of contrasting rice genotypes-Pusa sugandha-5 (drought-susceptible) and Nagina-22(drought-tolerant) under drought condition against priming with biotic elicitors- methyl jasmonate (MJ) and paclobutrazol (PBZ). Bars represent standard deviations.

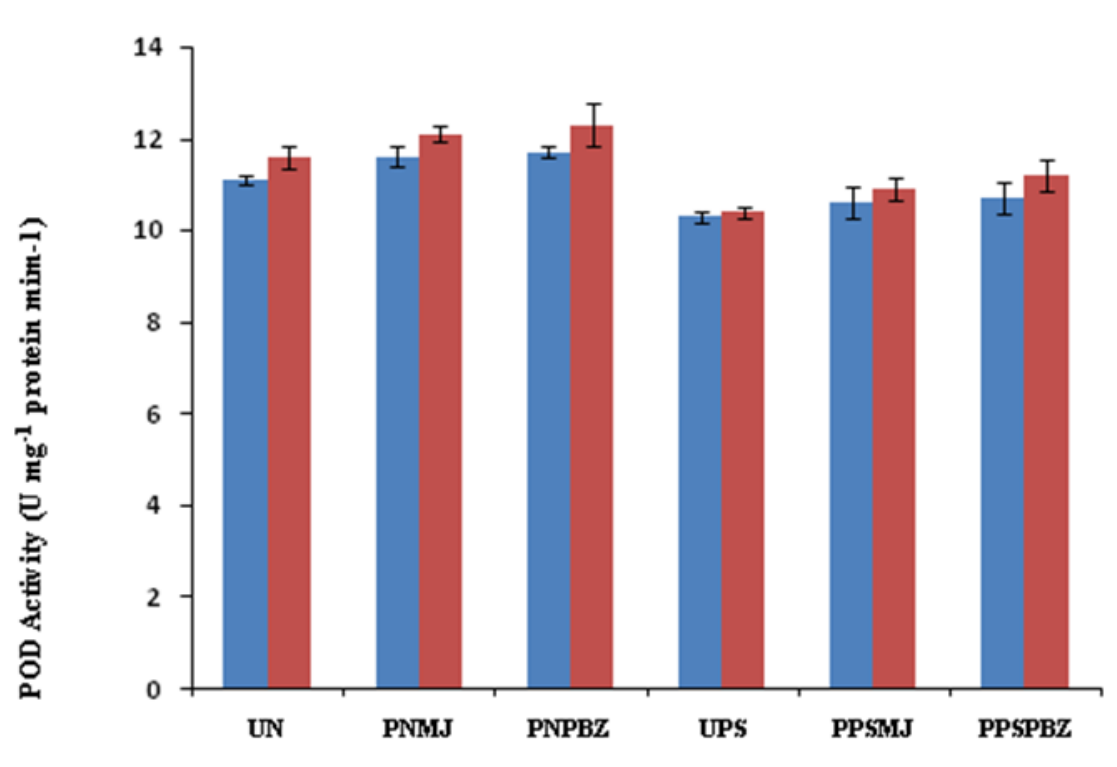

- Control

- Treated

Figure:4 POD Activity in shoot region of contrasting rice genotypes-Pusa sugandha-5 (drought-susceptible) and Nagina-22(drought-tolerant) under drought condition against priming with biotic elicitors- methyl jasmonate (MJ) and paclobutrazol (PBZ). Bars represent standard deviations. 
This suggests that the antioxidant system plays an important role in plant tolerance against environmental stress. Rice varieties showed lowest enzymatic activity under normal condition. This indicated plants will produce more CAT, SOD and POD under drought conditions to remove the ROS. In this study, CAT SOD and POD activities increased markedly in the drought tolerant varieties than the sensitive one. Droughttolerant varieties were efficient hunter of free radicals, which may result in better protection against oxidative stress. The CAT is one of the highest turnover rates for all enzymes with the potential to directly dismutate $\mathrm{H} 2 \mathrm{O} 2$ into $\mathrm{H} 2 \mathrm{O}$ and $\mathrm{O} 2$ and is indispensible for ROS detoxification in peroxisomes during stress condition (Sairam and Srivastava, 2001). Anion free radicals converted to $\mathrm{H} 2 \mathrm{O} 2$ by the SOD enzyme and detoxify to less toxic compound and the $\mathrm{H} 2 \mathrm{O} 2$ can be eliminated by CAT and POD (Hasheminasab et al., 2012). Moreover, POD also involved in various plant processes, including lignification (Hendriks et al., 1991), phenolic compound oxidation (Largrimini, 1991), regulation of cell elongation (Mohammadkhani and Heidari, 2008) and detoxification of toxic compounds such as $\mathrm{H} 2 \mathrm{O} 2$ (Chaparzadeh et al., 2004). Antioxidant enzymes provide tolerance to rice genotypes to environmental stresses. For exm. drought tolerant species of pigeon pea (Cajanuscajan) (Kumar et al., 2011), wheat (Triticumaestivum) (Hasheminasab et al., 2012; Omar, 2012) and black gram (Phaseolus mungo) (Pratap and Sharma, 2010) had higher activities of SOD, POD and CAT than the drought-sensitive species. Under water stress conditions, the proline content showed highest. Accumulation of proline content under water stress indicates accumulated proline might act as a compatible solute regulating and reducing water loss from the plant cell during water deficit (Yokota et al., 2006) and play important role in osmosis regulation (Fedina et al., 2002). Proline accumulation provides energy for survival and growth of the plant under oxidative stress (Kumar et al., 2011). Thus, the proline content is a good indicator for screening drought tolerant varieties in water stress condition (Bayoumi et al., 2008; Kumar et al., 2011; Rahdari et al., 2012).

In conclusion, the rice varieties in this study showed differential responses for proline accumulation and enzymatic activities measured. The scavenging system in drought tolerant variety nagina-22 exhibited higher CAT, POD and SOD activities, than in the drought susceptible variety (pusa sugandh-5). Thus, the drought tolerance of these rice varieties seems to be linked to the activities of these antioxidant enzymes. The drought tolerance of rice varieties could induce antioxidative enzyme system more efficiently, resulting in growth suppression and higher proline content under drought stress.

\section{Acknowledgment}

We acknowledge the division of biochemistry, Indian agriculture research institute, New Delhi and Indian council of agriculture research for providing a grant to this research.

\section{References}

Afzal, I., Basra, S.M.A., Farooq, M. and Nawaz, A. 2006. Alleviation of salinity stress in spring wheat by hormonal priming with $\mathrm{ABA}$, salicylic acid and ascorbic acid. Int. J. Agri. Biol., 8(1): 2328.

Akram, H.M., A. Ali, A. Sattar, H.S.U. Rehman and A. Bibi. 2013. Impact of water deficit stress on various physiological and agronomic traits of three Basmati rice (Oryzasativa L) cultivars. J. Anim. Plant Sci., 23(5): 1415-1423

Aebi, H.E. and H.U. Bergmeyer. 1983. Methods 
of Enzymatic Analysis, 3, Verlag Chemic, Deerfield Beach, FL.p273-286.

Akram, H.M., A. Ali, A. Sattar, H.S.U. Rehman and A. Bibi. 2013. Impact of water deficit stress on various physiological and agronomic traits of three Basmati rice (Oryzasativa L) cultivars. J. Anim. Plant Sci., 23(5): 1415-1423.

Athar, H., A. Khan and M. Ashraf. 2008. Exogenously applied ascorbic acid alleviates salt-induced oxidative stress in wheat. Environ. Exp. Bot., 63: 224-231.

Bates, L.S., R.P. Walden and I.D. Teare. 1973. Rapid determination of Free proline for water studies. Plant and Soil, 39: 205208.

Bayoumi, T.Y., M.H. Eid and E.M. Metwali. 2008. Application of physiological and biochemical indices as a screening technique for drought tolerance in wheat genotypes. Afr. J. Biotech. 7(14): 23412352.

Beauchamp, C. and I. Fridovich. 1971. Superoxide dismutase: Improved assays and an assay applicable to acrylamide gels. Anal. Biochem., 44: 276-287.

Chaparzadeh, N., M.L. D'Amico, R.A. KhavariNejad, R. Izzo and F. Navari-Izzo. 2004. Antioxidative responses of Calendula officinalis under salinity conditions. Plant Physiol. Biochem., 42: 695-701.

Demiral, T. and I. Turkan. 2005. Comparative lipid peroxidation, antioxidant defense system and proline content in roots of two rice cultivars differing in salt tolerance. Environ. Exp. Bot., 53: 247-257.

Dhindsa, R.S., P. Plumb-Dhindsa and T.A. Thorne. 1981. Leaf Senescence: Correlated with increased levels of membrane permeability and lipid peroxidation and decreased level of superoxide dismutase. J. Exp. Bot. 32: 93101.

Fedina, I.S., K. Georgieva and I. Grigorova. 2002. Light-dark changes in proline content of barley leaves under salt stress. Inst. Plant Physiol. 45(1): 59-63.

Fraser, T., W. Silk and T. Rosr. 1990. Effect of low water potential on cortical cell length in growing region on maize roots. Plant Physiol., 93: 648-651.

Gupta, P.C. and J.C. O'Toole. 1986. Upland rice: a global perspective. Los Banos, Laguna, IRRI. Hasheminasab, H., M.T. Assad, A. Aliakbari and R. Sahhafi. 2012. Influence of drought stress on oxidative damage and antioxidant defense systems in tolerant and susceptible wheat genotypes. J. Agric. Sci., 4(8): 20-30.

Hendriks, T., H.J. Wijsman and L.C. Van Loon. 1991. Petunia peroxidase a: Isolation, purification and characteristics. European J. Biochem., 199: 139- 146.

Jebara, C., M. Jebara, F. Limam and M.E. Aouani. 2005. Changes in ascorbate peroxidase, catalase, guaiacol peroxidase and superoxide dismutase activities in common bean. Phaseolus vulgaris) nodules under salt stress. J. Plant Physiol. 162: $929-936$

Ji, K.X., Y.Y. Wang, W.N. Sun, Q.J. Lou, H.W. Mei, S.H. Shen and H. Chen. 2012. Drought-responsive mechanisms in rice genotypes with contrasting drought tolerance during reproductive stage. $J$. Plant Physiol. 169: 336-344.

Kaur, G., S. Kumar, H. Nayyar and H.D. Upadhyaya. 2008. Cold stress injury during the pod-filling phase in chickpea. Cicer arietinum L.): effects on quantitative and qualitative components of seeds. J. Agron. Crop Sci. 194(6): 457464.

Khan, M.H. and S.K. Panda. 2008. Alterations in root lipid peroxidation and antioxidative responses in two rice cultivars under $\mathrm{NaCl}$-salinity stress. Acta Physiol. Plant 30: 81-89.

Kumar, R.R., K. Karajol and G.R. Naik. 2011. Effect of polyethylene glycol induced water stress on physiological and biochemical responses in pigeon pea. Cajanuscajan L. Mill sp.. Recent Res. Sci. Tech. 3(1): 148-152.

Largrimini, L.M. 1991. Wound-induced deposition of polyphenols in transgenic plants over expressing peroxidase. Plant Physiol. 96: 509-516. 
Luck, H. 1974. Methods of Enzymatic Analysis. 2, Academia Press, New York, p885-894. Mohammadkhani, N. and R. Heidari. 2008.

Drought induced accumulation of soluble sugars and proline in two maize varieties. World Appl. Sci. J. 3(3): 448-453.

Omar, A.A. 2012. Impact of drought stress on germination and seedling growth parameters of some wheat cultivars. Life Sci. J. 9(1): 590-598.

Parida, A.K. and A.B. Das. 2005. Salt tolerance and salinity effects on plants. Ecotoxicol.Environ. Safety 60: 324-349.

Pessoa-Filho, M., A. Belo, A.A.N. Alcochete, P.H.N. Rangel and M.E. Ferreira. 2007. A set of multiplex panels of microsatellite markers for rapid molecular characterization of rice accessions. $B M C$ Plant Biol. 7: 23.

Pireivatloum, J., N. Qasimov and H. Maralian. 2010. Effect of soil water stress on yield and proline content of four wheat lines. Afr. J. Biotech.9: 36-40.

Pratap, V. and Y.K. Sharma. 2010. Impact of osmotic stress on seed germination and seedling growth in black gram. Phaseolus mungo. J. Environ. Biol. 31(5): 721-726.

Putter, J. 1974. Methods of Enzymatic Analysis, 2, Academia Press, New York, p865.

Rabello, A.R., C.M. Guimaraes, P.H.N. Rangel, F.R. da Silva, D. Seixas, E. de Souza, A.C.M. Brasileiro, C.R. Spehar, M.E. Ferreira and A. Mehta. 2008. Identification of drought-responsive genes in roots of upland rice. Oryzasativa L. BMC Genomics 9: 485-497.

Rahdari, P., S.M. Hosseini and S. Tavakoli. 2012. The study effect of drought stress on germination, proline, sugar, lipid,protein and chlorophyll content in purslane. Portulacaoleracea L.) leaves. $J$. Med. Plants Res. 6(9): 1539-1547.

Roy, R.N. and R.V. Misra. 2002. Economic and environmental impact of improved nitrogen management in Asian ricefarming system. In: Proceedings of the 20th Session of the International Rice Commission pg 23-26.

Sairam, R.K. and G.C. Srivastava. 2001. Water stress tolerance of wheat. Triticumaestivum L.): variations in hydrogen peroxide accumulation and antioxidant activity in tolerant and susceptible genotypes. J. Agron. Crop Sci. 186: 63-70.

Thakur, P., S. Kumar, J.A. Malik, J.D. Berger and H. Nayyar. 2010. Cold stress effects on reproductive development in grain crops: an overview. Environ. Exp. Bot. 67(3): 429-443.

Vranová, V., D. Inzé and F. Van Breusegem. 2002. Signal transduction during oxidative stress. J. Exp. Bot. 53: 12271236.

Yokota, A., K. Takahara and K. Akashi. Physiology and molecular biology of stress tolerance in plants. In: Madhavarao, K. Raghavendra and K. Janardhanreddy. eds), pp15-40, Springer.

\section{How to cite this article:}

Samota, M.K., M. Sasi and Singh, A. 2017. Impact of Seed Priming on Proline Content and Antioxidant Enzymes to Mitigate Drought Stress in Rice Genotype. Int.J.Curr.Microbiol.App.Sci. 6(5): 2459-2466. doi: https://doi.org/10.20546/ijcmas.2017.605.275 